Article

\title{
The Method of Combating Coal Spontaneous Combustion Hazard in Goafs-A Case Study
}

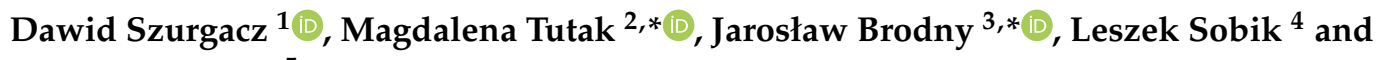 \\ Olga Zhironkina ${ }^{5}$ \\ Center of Hydraulics DOH Ltd., 41-906 Bytom, Poland; dawidszurgacz@doh.com.pl \\ 2 Faculty of Mining, Safety Engineering and Industrial Automation, Silesian University of Technology, \\ 44-100 Gliwice, Poland \\ 3 Faculty of Organization and Management, Silesian University of Technology, 44-100 Gliwice, Poland \\ 4 Polska Grupa Górnicza S.A. KWK ROW Ruch Chwałowice, 44-206 Rybnik, Poland; sobik55@poczta.fm \\ 5 Foreign Language Department, Kemerovo State University, 650000 Kemerovo, Russia; o-zhironkina@mail.ru \\ * Correspondence: magdalena.tutak@polsl.pl (M.T.); jaroslaw.brodny@polsl.pl (J.B.)
}

Received: 31 July 2020; Accepted: 31 August 2020; Published: 2 September 2020

check for updates

\begin{abstract}
One of the major natural hazards occurring during the process of mining exploitation are endogenous fires. They cause very large material losses and constitute a threat to the health and life of the workers. Such fires usually start and develop in the goafs. The remaining coal and the oxygen-containing air flowing at a certain rate may lead to endogenous fires. The basic element of the assessment of the occurrence of an endogenous fire and the degree of its development is the chemical composition of the air flowing out of the longwall and the goafs. The monitoring of this composition also makes it possible to assess the severity of such a fire. The damage that can be caused by the endogenous fire requires scientific and experimental research being carried out on a wide scale in order to limit its occurrence and development. All papers and research mentioned in the paper aim to find a tool that will help to control the fires. The paper discusses the development of a new and original method of combating the threat of endogenous fires. It is based on the installation designed to feed an ash and water mixture or an ash and water mixture with carbon dioxide to goafs. The foundation of the paper is a method based on a vast depth of expertise and knowledge gained by the authors in the field of combating endogenous fires. The developed installation prepares and transports ash and water mixtures together with carbon dioxide to the zones with high probability of endogenous fires. The mixture is a preparation of the surface of a mine, and later, it is transported underground by pipelines to the goafs where a high level of the fire hazard was identified. The construction of the system and the composition of the mixture used are both original solutions; their practical application limited the process of spontaneous heating of coal. Monitoring the chemical composition of gases in the air of the goafs made it possible to control the effects of applied measures; it proved that carbon dioxide used as an inert gas disturbs the process of carbon oxidation, and the water and ash mixture limits the inflow of the air with oxygen. The advantage of the method is particularly evident in the case of the exploitation of deposits where coal has a short incubation time. This original approach allows for a better and more effective response to endogenous fires.
\end{abstract}

Keywords: spontaneous combustion of coal; endogenous fire hazard; underground mining; ash-water mixture; inertisation 


\section{Introduction}

Coal is mainly used to generate electricity: As commercial heat in households and different branches of the industry [1-4]. The global forecast of coal resources estimates that the coal resources will last for another 130 years [5]. Coal is the third-largest source of primary energy. Its position will continue to be high in the world in terms of energy consumption. Unfortunately, the mining industry is linked to a high-risk factor in terms of work safety, difficulty in mining, and geological conditions [6-9]. One of the most dangerous natural hazards are endogenous fires, commonly referred to in the literature as spontaneous combustion of coal [10].

The issues related to the formation of an endogenous fire are vital for the work safety of mining teams and ensuring continuity and efficiency of the coal production process-it is confirmed by the fact that despite the decreasing level of extraction, the number of dangerous events related to such fires is increasing. The effects of these incidents are also often tragic; this particularly concerns the health and life of mine workers. It should also be emphasized that these events result in interruptions in the work of the whole mining facility, the need to isolate mining fronts, and other issues that negatively impact on the company's economic efficiency [11,12].

The increase in the intensity of events related to the endogenous fires hazard makes it necessary to take actions aimed at ensuring that the safety and health of employees are protected and limiting the economic losses of hard coal production companies as effectively as possible. Such fires usually occur in longwall goafs [13-15].

A goaf is a space or a void created when a portion of coal is extracted, filled with rock rubble created as a result of the cave-in of roof rocks deposited above the exploited seam. The goafs always have free spaces that are not filled with any rock material $[16,17]$. These spaces, i.e., non-closed points between chaotically arranged blocks of broken roof rocks, form a specific kind of porous medium through which gases, including air migrating from the exploitation longwalls, can flow. The goafs play an essential role in the formation of ventilation hazards in the area of the operation, therefore it is necessary to insulate them [18].

Some amount of airflow migrates to the goafs during the routine ventilation of underground workings. Part of the air stream fed to the longwall is divided into two streams-one flows into the longwall, the other one is directed towards the goaf.

Due to the fact that the goafs are porous and permeable, the air travels in both directions-from longwall to the goaf and from the goaf towards the longwall. The intensity of such flows depends on many factors, mainly the physical parameters of flowing gases and the permeability of goafs [19-23]. It is obvious that this also has a very significant impact on the formation of the hazard of endogenous fires in the area of active mining works. Air migrating from the longwall to the goaf creates conditions for spontaneous combustion of the coal that was left in the goaf. The air-a mixture of gases-flowing through the pores and crevices in the goafs can activate them thermally, causing the release of fumes, open fire, and the emission of combustion products into the atmosphere in the form of poisonous gases.

Coal spontaneous combustion is preceded by oxidation of coal that leads to spontaneous heating of coal which is followed by spontaneous combustion. The heat generated during the oxidation reaction accumulates, causing the temperature to rise to the point of ignition. These reactions and favourable conditions are followed by spontaneous combustion and fire [24-26].

The mechanism of the reaction of oxygen with carbon is chemical, thus having strong toxic properties.

In the event of an endogenous fire in goafs or other areas of the mine, the ventilation air stream becomes a source of oxygen supporting the coal oxidation process and a carrier of fumes and fire gases moves to subsequent mine workings. In terms of safety, it is therefore crucial to maintain the optimum composition of the atmosphere. This is possible thanks to the inertisation process of the goafs. Inerting is the process of injecting substances (such as an inert gas) into the goafs to reduce the oxygen concentration; it leads to the interruption of the spontaneous combustion of coal or does not allow it to start at all (Figure 1). 


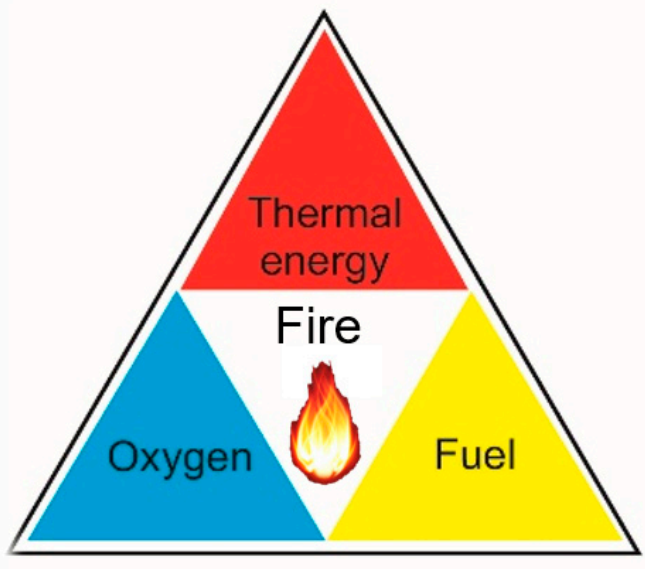

Figure 1. Impact of the inert gas on the combustion process (own elaboration based on [27]).

For the inerting process to proceed properly, it is necessary to identify in advance where the coal spontaneous heating process leading to the spontaneous combustion has occurred.

The authors designed a method to limit the spontaneous fire hazard in the goafs. This method involves the simultaneous application of both in situ and model tests. Until now, such an approach has not been used to analyse the risk of spontaneous combustion of coal in hard coal mines in Poland. This method consists of two basic stages. The first step is to identify the area where the probability of the endogenous fire hazard is high using numerical simulation-its detailed description is presented in previous papers $[28,29]$. The physical and chemical parameters of the air in such areas reach critical values that are conducive to the initiation of low-temperature carbon oxidation. Determination of this zone in real conditions is practically impossible because it is formed in the inaccessible area of the goafs, however, the knowledge of this area makes it possible to precisely locate the part in the goaf to which the ash and water mixture and/or inert gases must be fed. The second step of the developed method involves preparing the surface installation for feeding the ash and water mixture with carbon dioxide or carbon dioxide alone to prevent an endogenous fire in the area. The ash and water mixture is fed to longwall excavations from the surface through a network of pipelines for underground excavations.

The originality of this method lies in the identification of an endogenous fire hazard area and the feeding of an ash and water mixture or an ash-water mixture with inert gas (carbon dioxide and/or nitrogen) and anti-pyrogenic foam into this area through pipelines.

Following the identification of the zone where the probability of coal spontaneous combustion is high, the water and ash mixture was supplied simultaneously with the carbon dioxide as the inert gas. The efficiency of the solution was assessed by controlling the composition of the air that flows out of the face area (including the goafs). The authors of the paper hope that the presented method will contribute to the discussion on methods of combating the hazard of endogenous fires. This method defines a new direction and approach to the broadly understood safety and efficiency of the coal production process. The method can be used to reduce the hazard of endogenous fires not only in underground excavations of hard coal mines but on coal heaps or post-mining waste. The effectiveness of the method is particularly evident in the case of the exploitation of deposits where coal has a short incubation time.

There are several features of the method developed to prevent and limit the occurrence of endogenous fires caused by coal spontaneous combustion that prove its originality. First, before the mixture is fed into the goafs, a zone is identified based on numerical simulations in which the conditions for initiating the carbon oxidation process leading to spontaneous combustion are met. Second, the installation which delivers the mixture to the goaf is used for the seam located at a depth below $700 \mathrm{~m}$. The installation consists of a network of pipelines and its capacity is over 100 tonnes per 
hour. Additionally, the dosage of components (ash, water) and the density of the mixture are recorded by a computer visualisation and control system. Finally, the composition of the mixture that is fed to the goafs is new and is combined with the simultaneous delivery of an inert gas $\left(\mathrm{CO}_{2}\right)$. The function of this gas is to limit the potential for spontaneous heating of coal by limiting its oxidation. In turn, only those fly ashes which additionally contain calcium oxide $(\mathrm{CaO})$ are used for the water and ash mixture. Thanks to the good penetrating and binding properties of this mixture, it seals the goaf, thus limiting the possibility of oxygen supply to the zone.

The use of simultaneous injection of water and ash mixture and an inert gas into a previously identified fire hazard zone is a new approach towards reducing the effects of an endogenous fire hazard.

\section{Literature Review}

Endogenous fires are usually characterised by a calm course, with generally early external signs thanks to which the hazard is detected early and appropriate measures can be applied [30,31]. Endogenous fires are among the most common fires in underground hard coal mines, which is associated with the flammability of coal and its high susceptibility to spontaneous combustion [32]. Fighting endogenous fires through a widely conducted fire prevention and thus preventing spontaneous heating and spontaneous combustion of coal come down to eliminating one of the following factors necessary for the occurrence of a fire [33-35]:

1. The presence of combustible material (such as crushed carbon prone to low-temperature oxidation);

2. The existence of an air supply to coal that accumulated;

3. Possible accumulation of the heat emitted during the oxidation reaction;

4. The first factor is related to the properties of coal substances, while the remaining ones depend on the mining and geological conditions, the mining system, the method of ventilation, or the mining face.

All longwalls in Polish hard coal mines use the system that runs from the border with roof caving. As a result, there is a potential for coal to enter the goaf, and thus a high probability of the endogenous fire.

The main reasons for the formation of crushed coal in the goaf include:

1. A patch of coal left to support the weak roof;

2. Thin deposits not suitable to be extracted, located close to the extracted deposits-mining of deposit strata;

3. A patch of coal left under the roof or on the floor with the roof support not adapted to the conditions.

The fire hazard in the goafs usually increases when a longwall is periodically stopped, slowed down, as well as after the end of the operation at the place where it was stopped and during decommissioning.

\subsection{Coal Spontaneous Combustion Hazard in Goafs_-Prevention}

The method of limiting the hazard of spontaneous heating of coal left in the goafs using inertisation is known since the nineteenth century. As early as 1850, a gas mixture consisting of steam, carbon dioxide, nitrogen, and sulphur dioxide was used at the Clackmannan Coal Mine in Scotland, seven miles from Sterling. This mixture was produced in the furnace and fed by means of a water jet pump [36]. The methods to reduce the hazard of spontaneous combustion of coal in the goafs are being continuously improved ever since.

There are two main approaches related to reducing the hazard of coal spontaneous combustion in the goafs based on inerting systems. One of them is known as proactive and the other as reactive. The proactive method involves preventive measures implemented in advance, i.e., before any signs of coal spontaneous heating occur. The reactive method involves the inerting of the goafs only when the process of coal spontaneous heating is detected. In reference [37], the authors compared these two contrasting approaches related to the inerting of goafs, using the "what, if" scenario method. 
In general, there are several important research works that discuss measures used to prevent and reduce the coal spontaneous combustion in the goafs, including feeding of different mixtures to the goafs. Zhou et al. applied a three-phase foam, consisting of silt, nitrogen, and water, to stop a fire in the Baijigou Coal Mine of Ningxia Province in China [33]. The foam was injected into the fire zone in the goafs through holes drilled on the surface. Colaizzi in his paper [34] presented a method of fire control through the use of the Thermocell technology in which the fire zone is supplied with a suspension consisting of sand, cement, water, and high content of fly ash (a by-product of coal combustion), to which a certain amount of aeration foam (similar to shaving cream) is also added. The result is a lightweight mortar that is extremely heat resistant and very liquid.

Zhang, in turn [38], proposed inertisation of goafs with the use of a gel that is a good material for combining water and particles. There are three types of gels used in China to extinguish fires: Gelatum, thickening gel, and composite gel.

Liu and Weng in their paper [39] presented the $\mathrm{N}_{2}$-inhibitor-water mist (NIWM) technology to prevent and extinguish fires in the goafs in hard coal mines.

In [40], the authors presented the influence of various mixtures pumped into the goaf on the process of coal spontaneous heating.

Several papers present computational fluid dynamics (CFD) as a measure to fight endogenous fires. References [41-45] present proactive methods of inerting the goafs, including the CFD method. Ren and Balusu [41] described the method of proactive goaf inertisation for controlling longwall goaf heating based on CFD. Si et al. [42] presented a manner of optimizing the injection of carbon dioxide into goafs from multiple sources on the basis of orthogonal test and fuzzy complex theory. Zhang et al. [43] described the proactive inertisation in longwall goaf for the coal spontaneous combustion control with the computational fluid dynamics approach. The authors of [44] described the results of research on optimization of technical parameters of carbon dioxide inertisation of goafs from one of the hard coal mines. Classen [45] described the method of inerting and sealing the goaf with the use of methane coming from the system of gas extraction from the deposit. Morla et al. [46] conducted a wide range of parametric studies to develop proactive strategies to prevent oxygen from entering the goaf in order to reduce the spontaneous heating of coal.

In terms of inertisation of goafs, it is essential to determine the zone in goafs to which specific mixtures should be fed. The authors of [28] present the methodology of determining such a zone in the goaf, depending on the value of the tensile strength of roof rocks. In the work [47], however, such a zone was determined with regard to the amount of air supplied to the longwall in the process of ventilating it. These zones are identified based on numerical simulations. Each zone is determined for specific and known geological and mining conditions in which a given longwall is operated. Adequate oxygen concentration in the air and an adequate filtering speed of the flowing air must be provided. Several works give different critical values for oxygen concentration and airflow speed. Cheng et al. assumed that the value was within 0.004 to $0.0016 \mathrm{~m} / \mathrm{s}$ [48]. Chumak et al. [49] assumed that the critical value of speed was between 0.015 and $0.0017 \mathrm{~m} / \mathrm{s}$. Szlazak, in turn, stated that this value fell between 0.015 and $0.0015 \mathrm{~m} / \mathrm{s}$ [50]. Wang et al. [51] specified that this value ranges from 0.001 to $0.02 \mathrm{~m} / \mathrm{s}$.

In the case of oxygen concentration in the air flowing through the goafs, it has been shown that the lower limit at which coal spontaneous combustion occurs is $8 \%$. The results of the study carried out by Buchwald [52] indicate that below this value, no spontaneous combustion of coal occurs due to insufficient oxygen concentration.

All the presented works, which are only a part of the extensive publication output in this area, indicate that the problem of goaf inertisation is relevant from the perspective of ensuring the safety of the mining process. This is due to the fact that hard coal remains one of the most important energy resources in the world, and its safe and economically viable extraction is its key element. Therefore, it is necessary to apply methods which, on the one hand, improve safety conditions at work and prevent 
economic losses and, on the other hand, reduce the adverse impact of by-products of spontaneous combustion of coal on the environment.

That is why it is vital to take the necessary steps to reduce at least one of the most dangerous hazards in the exploitation of this raw material.

The literature review shows that the presented method designed to reduce the spontaneous fire hazard is innovative and original.

\subsection{The Issue of the Barometric Surge in Underground Excavations and Its Impact on the Endogenous Fire Hazard}

An important issue related to the problem of endogenous fires in the goafs is the occurrence of changes in atmospheric pressure. The problem of changes in this pressure also concerns the methane release hazard and generally the ventilation processes in underground mines. This phenomenon results from natural changes in atmospheric pressure, causing the phenomenon referred to as "breathing" of goafs.

References [53-59] have drawn attention to the danger of starting the process of coal spontaneous heating and of creating or reactivating this process during the phenomenon of pressure surges.

The phenomenon of so-called atmospheric pressure surges (occurrence of the barometric surge) is particularly dangerous, as it results in easy penetration of air into the goafs and limits the amount of methane flowing out of the goafs. The oxygen air injected into the goafs can initiate or stimulate an endogenous fire. In turn, the occurrence of barometric low (pressure drop), causes these gases to flow out which is also dangerous. Therefore, preventive measures should recognise these phenomena. The effectiveness of the area dam system is crucial here. It is advisable to strive for the elimination of the influence of atmospheric pressure on the migration of gases through goafs or coal pillars connecting the active excavations with the dammed ones, where mining works are often conducted in the vicinity. A concept was developed by Bystron for this purpose (the concept of maintaining a constant pressure in the mining workings) [56]. It involves the use of the main fan with a large control range (installed at the exhaust shaft), cooperating with the control dam installed in the total flow of fresh air (supplied to the excavations). This method is based on the assumption that the aerodynamic resistance of this dam and the stagnation of the main fan, depending on changes in air pressure, should be regulated in such a way that the air pressure in the mine workings does not change much. Another method of reducing the influence of changes in atmospheric pressure on the goafs is the use of the so-called equalization chambers. However, with significant changes in this pressure, as well as with the existence of complex connections between the dammed areas and active workings by means of compensation chambers, it is generally impossible to achieve complete elimination of the influence of barometric pressure changes on the goaf "breathing" [60]. In the 1990s, a concept was developed to limit the impact of barometric pressure changes on the hazard of coal spontaneous combustion in underground mine workings that is based on appropriate regulation of the internal source of gas $\left(\mathrm{CO}_{2}, \mathrm{~N}_{2}\right.$, or $\left.\mathrm{CH}_{4}\right)$ or water. However, this method requires the installation of an inert gas supply system to the dammed zone [60].

\section{Materials and Methods}

\subsection{Description of the Study of the Hard Coal Mine}

The method presented in the paper designed to combat the endogenous fire hazard (such as coal spontaneous combustion) in the goafs was implemented in KWK ROW Ruch Chwałowice in Rybnik, Poland (Figure 2). KWK ROW Ruch Chwałowice, which is a part PGG S.A. Group, is located in the southern part of Poland, in (Rybnik Mining District). The KWK ROW Ruch Chwałowice Coal Mine launched coal production in 1907 [61]. The size of its mining area is $21.76 \mathrm{~km}^{2}$ and its operational resources amount to 144,643 thousand tons of coal. The KWK ROW Ruch Chwałowice Coal Mine is a medium gassy mine. The tendency of coal to spontaneously combust was defined as medium, large, and very large, which corresponds to groups III to $\mathrm{V}$ of spontaneous combustibility as defined 
by Polish regulations. Coal seams are also classified as class A and B coal dust explosion hazards. The rock mass in the area of the mine does not tend to burst, which means that there is no rockburst hazard. Fully mechanised mining and fully mechanised caving methods are adopted at all working faces of the longwall. Currently, the main operating depth of the plant is about $700 \mathrm{~m}$.

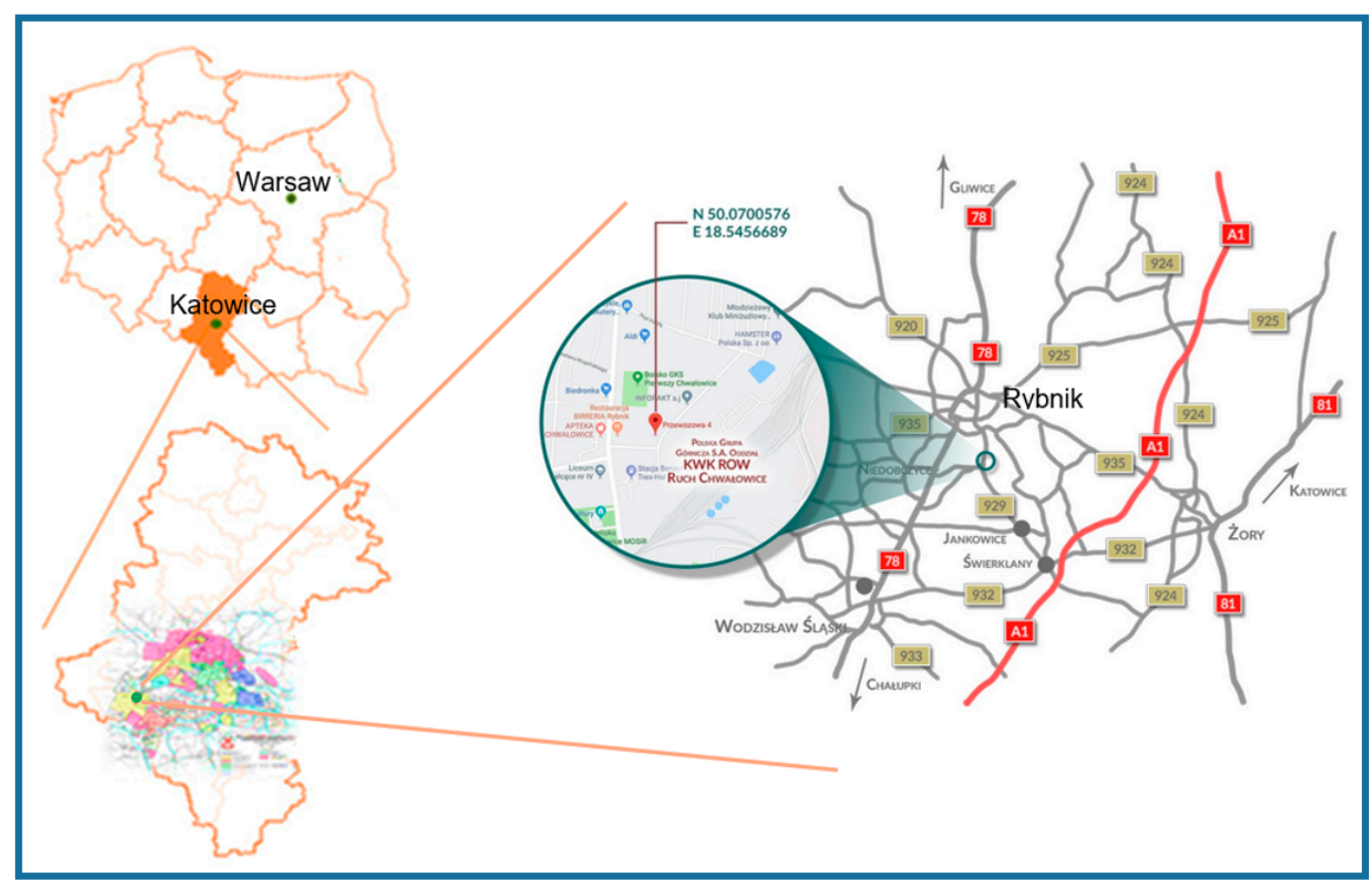

Figure 2. Location of the tested mine (own elaboration based on [61]).

The research was carried out in a longwall based on the longitudinal mining system with roof caving. The thickness of the seam in the longwall parcel was $1.9 \div 2.1 \mathrm{~m}$ on average. The length of the longwall was between 230 and $235 \mathrm{~m}$ and the length of the mining area of the longwall was about $480 \mathrm{~m}$. The longitudinal inclination of the longwall was between 20 and $22^{\circ}$, and the transverse inclination between 8 and $13^{\circ}$. The coal was mined at the depth of $700 \mathrm{~m}$ with the U-type ventilation system. The works were based on the cave-in of roof rocks and this consequently led to the formation of goafs and cracks in the rock mass. The goafs formed a porous medium that allowed the flow of gases including the air rich in oxygen migrating from the longwall area to the goafs. Simultaneously, methane and by-products of oxidation including carbon monoxide migrated from the goafs to the longwall area. The recorded rise of the concertation of carbon monoxide in the airflow forced the team to take necessary measures to deal with the rise. It was then necessary to develop a complex method that will limit the probability of coal spontaneous combustion in the goafs. This case required rapid and specific actions in order to minimize the fire hazard. Figure 3 presents the diagram of the longwall and the location of the pipeline that supplied the goafs with the ash and water mixture together with carbon dioxide. 


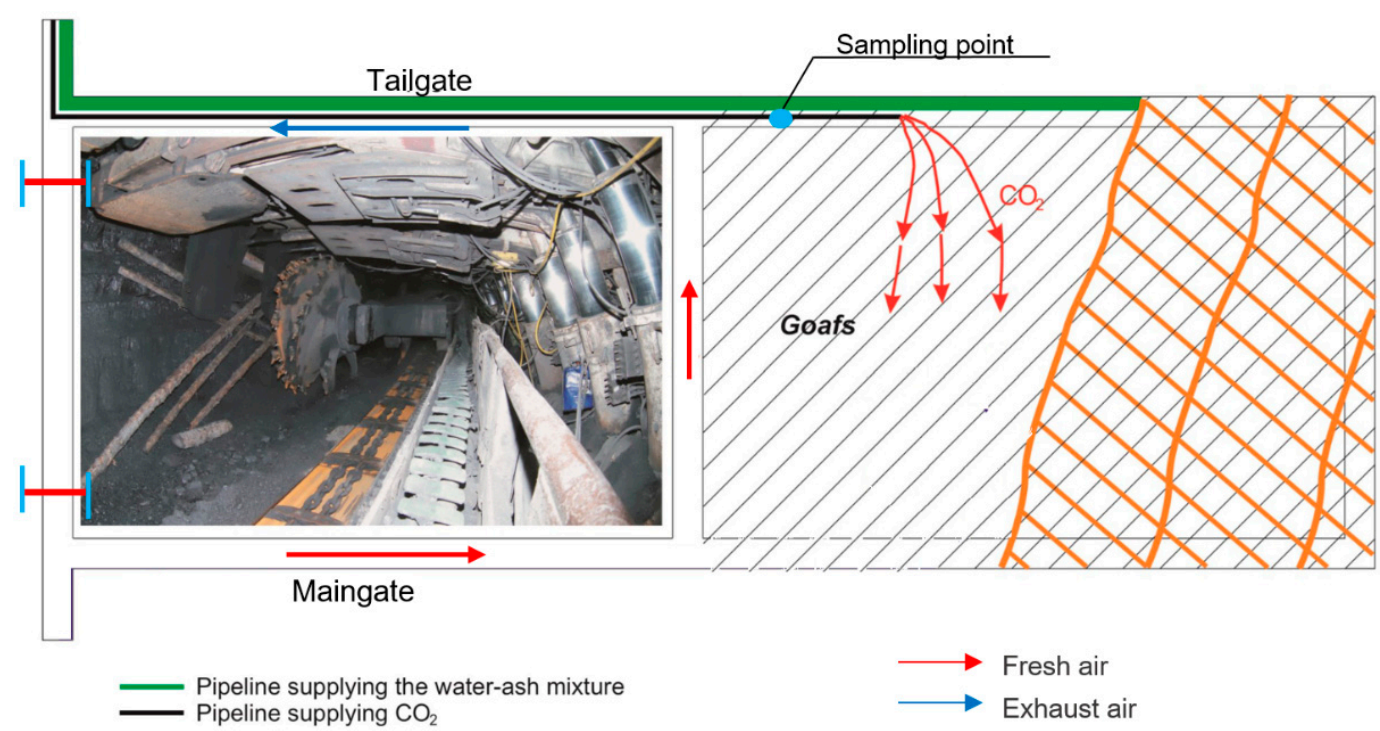

Figure 3. Diagram of the longwall and the location of the pipeline that supplied the goafs with the ash and water mixture together with carbon dioxide.

\subsection{The System for Preventing and Limiting Coal Spontaneous Combustion in KWK ROW Ruch Chwatowice}

The developed and implemented method designed to prevent and minimize coal spontaneous combustion in the goafs involves identification of the areas with a high fire hazard and supplying it with the ash-water mixtures with the inert gas (carbon dioxide). The numerical analysis that had been earlier discussed was used to identify the areas with a high hazard that reached $178 \mathrm{~m}$ deep into the goafs. A mixture of ash and water with carbon dioxide was fed to this zone.

The core part of this method was the development and construction of an airborne installation for the preparation and feeding of the ash and water mixture together with carbon dioxide or carbon dioxide itself to the goafs. The ash and water mixture was fed by means of a pipeline network. Prior to its administration, the capacity of the goaf $\left(V_{p}\right)$ was determined, which according to Equation (1) amounted to $151,250 \mathrm{~m}^{3}$ :

$$
V_{p}=c \cdot \frac{L H w}{\cos \alpha}
$$

where $L$ is the length of the longwall including the main gates $(235 \mathrm{~m}), H$ is the height of the working $(2.8 \mathrm{~m}), w$ is the mining area of the longwall $(480 \mathrm{~m}), c$ is the coefficient of water capacity of the working $(c=0.45)$, and $\alpha$ is the angle of inclination $\left(20^{\circ}\right)$.

The coefficient of water holding capacity in goafs can be determined approximately from the following Equation (2):

$$
c=1-a
$$

where $a$ is the rock mass settlement rate.

\subsection{Construction and Principle of Operation of the Developed Installation for Industrial Use of Fly Ashes}

The developed and constructed installation has a maximum capacity of up to 100 tonnes per hour of the ash-water mixture. The installation for the industrial use of fly ash has two ash tanks with a capacity of $225 \mathrm{~m}^{3}$ each $\left(2 \times 225 \mathrm{~m}^{3}=450 \mathrm{~m}^{3}\right)$, which can be filled from both road and rail tankers. It is equipped with a flow mixer, which allows for a continuous process of production. The fly ash is delivered to the mixer from the storage tank via dosing devices (cell-type feeder) and a screw conveyor. The capacity of the dosing units is regulated by a frequency converter and is adjusted to the mixer capacity, ranging from 20 to approximately $100 \mathrm{t} / \mathrm{h}$. In the mixer, ash is mixed in the appropriate ratio with saline water. Both ash and water are fed to the mixer through devices enabling continuous control of the flow rate through electromagnetic flowmeters. At the outlet of the mixer, 
the density of the mixture is controlled in an isotopic flow-through density meter. After the outlet from the mixer, the mixture is fed under gravity to the intermediate tank $\left(V=13 \mathrm{~m}^{3}\right)$ and further down the technological holes TP-1/2000 and TP 2/2008 underground to the level of $390 \mathrm{~m}$ and further down the pipelines to the goafs. The mixture is delivered to the goafs from the surface by a vertical pipeline directly to the depth of $390 \mathrm{~m}$ (technological hole no. TP-1/2000). Then, the mixture is transported through horizontal pipelines to the next technological hole (TP-2/2008) that is used to transport it further to a depth of $700 \mathrm{~m}$. The entire process of vertical transport of the mixture is divided into two stages, which is mainly determined by the specificity of the mine (structure of vertical excavations and technological holes). The developed method, depending on the structure of vertical excavations (technological holes) and their accessibility, also features direct delivery of the mixture from the surface to a given depth.

The dosage of components (ash, water) and the density of the mixture are recorded by a computer visualisation and control system. Figure 4 illustrates the concept of the arrangement of the installation on the surface and how the ash-water mixture together with carbon dioxide is fed. Figure 5 shows the construction of an installation for industrial use of fly ashes together with a carbon dioxide tank. Figure 6 shows the actual installation site for the industrial use of fly ashes with a carbon dioxide tank. 


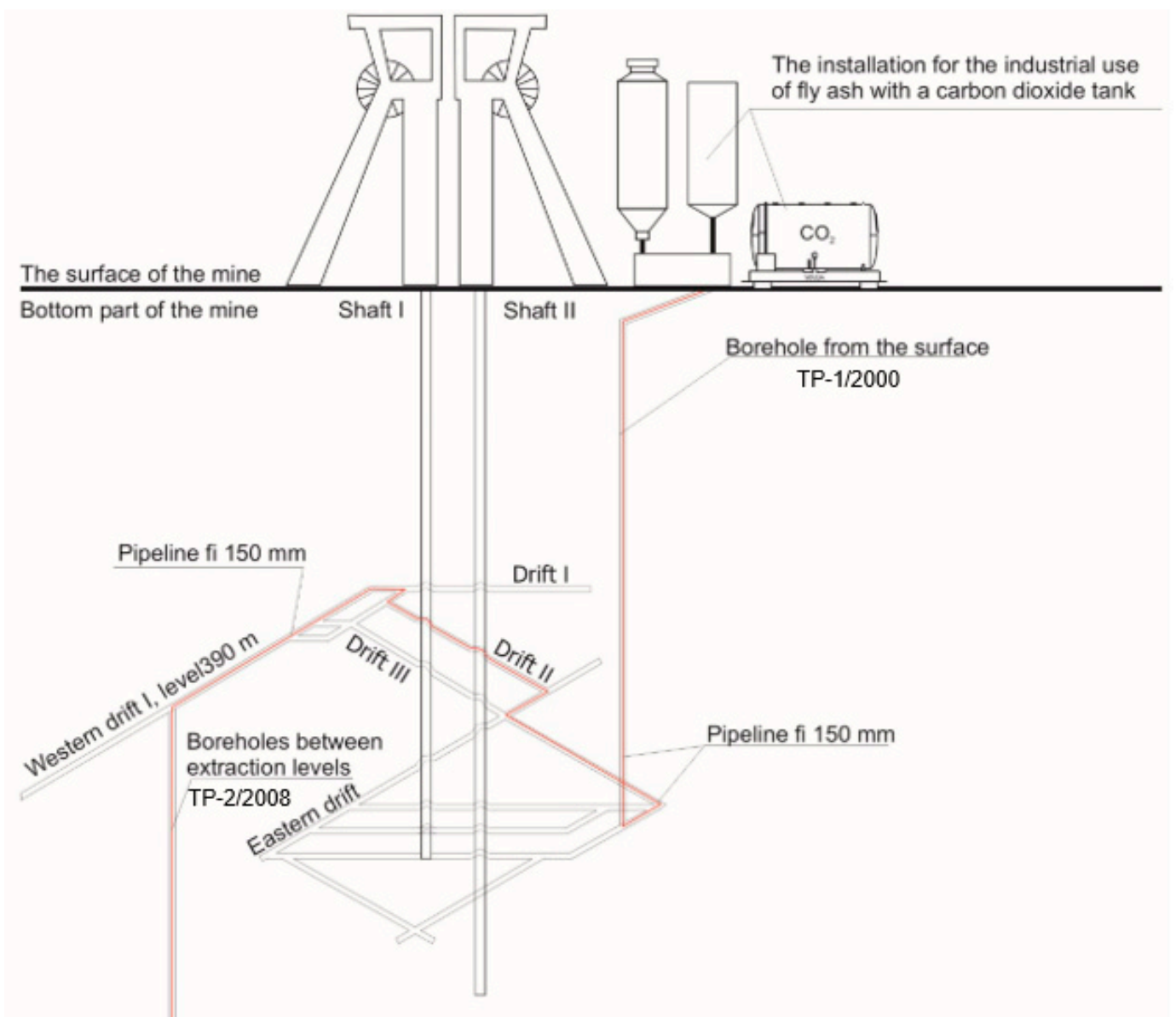

Pipeline fi $150 \mathrm{~mm}$

Figure 4. Conceptual arrangement of the installation for the industrial use of fly ashes together with a carbon dioxide tank and the manner it is fed to the longwall area. 


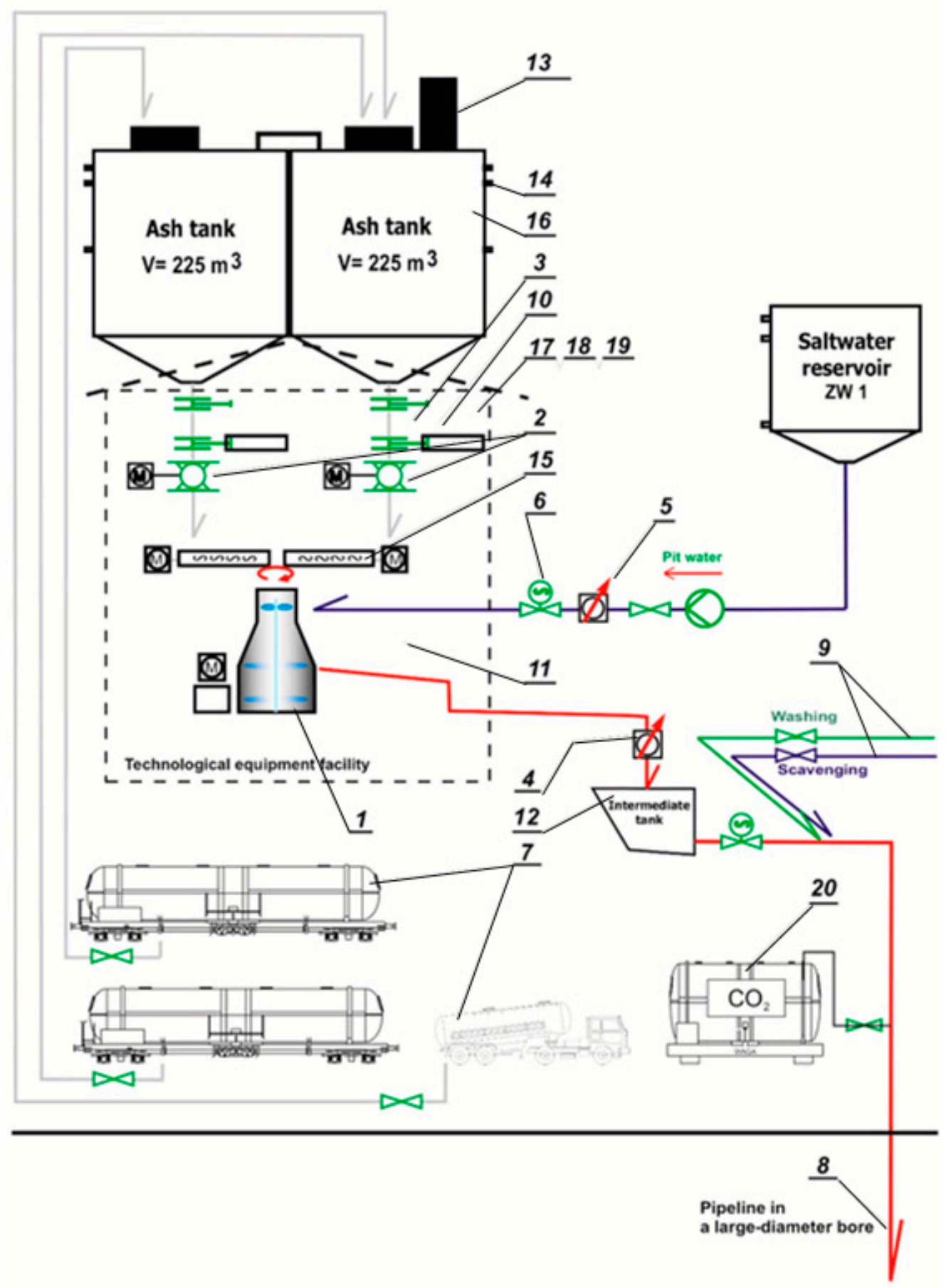

Figure 5. Construction of the installation for the industrial use of fly ash, including a carbon dioxide tank (1-mixer, 2-dosing device, 3-bolts under tanks, 4-density meter, 5-flow meter, 6-control valves, 7-unloading station from railway cars and road tankers, 8-pipeline in the shaft, 9-pipelines within the installation, 10-electrical and automation installations, 11-preparation of compressed air, 12-compressed air tank, 13-dedusting device, 14-level gauge, 15-conveyor, 16-ash tank, 17-installation buildings and control room, 18-installations in $\mathrm{CO}$ building, water, and sewage system, 19 -lighting, $20-\mathrm{CO}_{2}$ tank). 


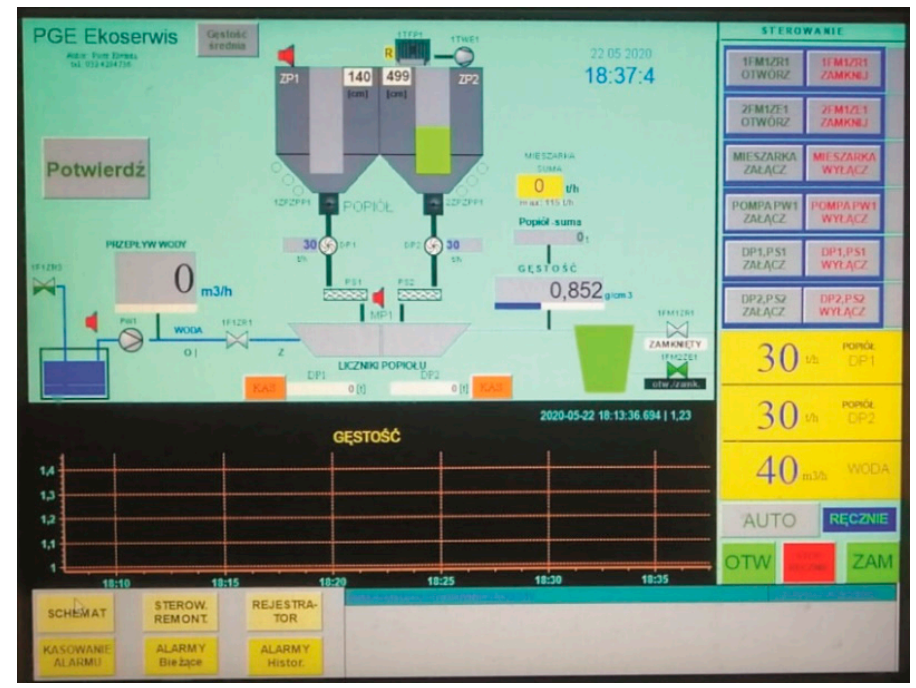

(a)

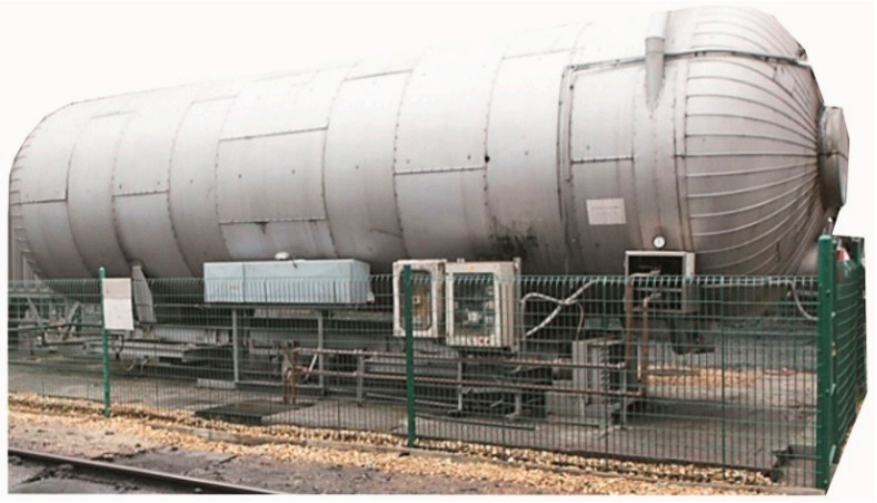

(b)

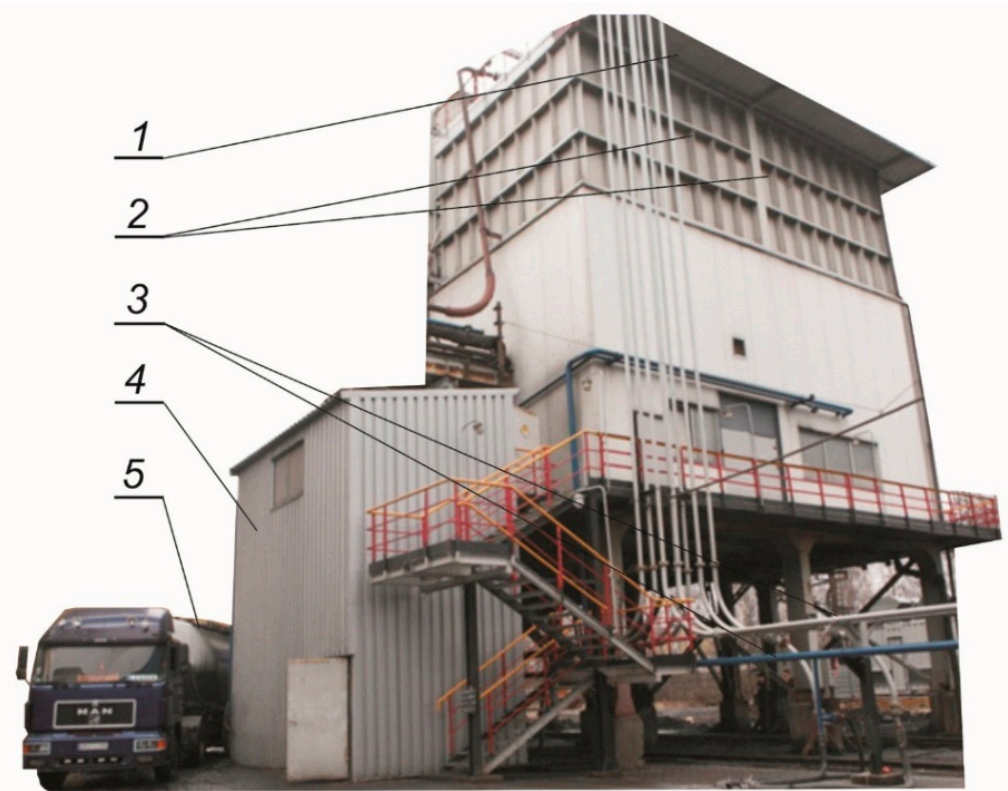

(c)

Figure 6. The actual installation for the industrial use of fly ashes together with the carbon dioxide ((a) The computer visualisation and control system; (b) $\mathrm{CO}_{2}$ tank, (c) The installation building and equipment, where: 1-installation building, 2-ash tanks located above the building, 3-pipelines within the installation, 4-technological equipment building, 5-unloading station for road tankers). 


\subsection{Properties of Ash and Water Mixtures}

The installation shown in Figure 5 was used to create the ash-water mixture. The energy waste (fly-ash) mainly comes from power plants as fly-ash from burnt coal and a mixture of fly-ash and solid waste from calcium flue gas desulphurisation methods (dry and semi-dry flue gas desulphurisation and fluidised bed combustion). Fly ash is also used as energy waste from a heat and power plant.

The ash and water mixture is made with an ash/water ratio of 1.2-1.4:1.0 using the installation whose selected components are presented in Figure 4. Mixing this weight ratio of ash and water gives a mixture of density between 1200 and $1400 \mathrm{~g} / \mathrm{L}$.

The types of the fly ash differ in terms of chemical composition (mainly $\mathrm{CaO}$ content), which affects the ability to form suspensions, water binding, and spreading capacity and an important factor such as rheological properties. Fly ash delivered from both the coal and combined heat and power plant, due to the low $\mathrm{CaO}$ content in the range of $3.2 \div 3.5 \%$, is characterised by very weak binding properties, as opposed to ash containing, on average, $\mathrm{CaO}$ in the range of $14.2 \div 14.7 \%$, which forms a well-binding mixture of ash and water. In conclusion, as the content of free calcium in the delivered ashes used for the preparation of the ash-water mixture increases, the time of their setting decreases, which is a desirable factor due to the use in the sealing of the longwall goafs in underground conditions.

\subsection{The Properties of Carbon Dioxide and Technical Conditions for Its Use}

Carbon dioxide is an unlimited chemical compound also referred to as carbon anhydride. It is a non-flammable, colourless, and odourless gas. The characteristic properties of carbon dioxide include its density $1.98 \mathrm{~kg} / \mathrm{m}^{3}$ at $0{ }^{\circ} \mathrm{C}$ and $0.1 \mathrm{MPa}$ and 1.529 concerning its air density ratio. At a pressure of about 40 at carbon dioxide is cooled and supplied at its own pressure with saturated steam. It is stored in tanks at pressures between 8 and 22 bar and temperatures between -43 and $-17^{\circ} \mathrm{C}$. Under normal pressure, carbon dioxide passes from the solid state to the gaseous state (sublimates), omitting the liquid phase at $-78.5^{\circ} \mathrm{C}$. Under increased pressure $\left(5.1\right.$ at) it can be liquefied at $-78.5^{\circ} \mathrm{C}$. One kilogram of liquid carbon dioxide is obtained after degassing at $+15^{\circ} \mathrm{C}$ and $0.1 \mathrm{MPa} 555 \mathrm{dm}^{3}$ of gaseous carbon dioxide [62].

Carbon dioxide dissolves very easily in water, neutralizes explosive solutions more strongly than nitrogen. The limited oxygen concentration is higher when diluting air with carbon dioxide than when diluting with nitrogen. This phenomenon can be explained by the higher thermal capacity of carbon dioxide. It also results in the extinguishing effect when diluting with inert gases, which is conditioned by the heat loss that is used to heat the diluting gases and to reduce the thermal effect of the combustion reaction. One of the advantages, unlike nitrogen, is its greater neutralization capacity, which can be expressed in a ratio of 1:1.88. It follows that $1 \%$ of carbon dioxide has the same neutralization effect as $1.88 \%$ of nitrogen. When using carbon dioxide as an extinguishing material, it should be remembered that although it is an inert gas and hardly reacts with other substances, when the contact is made with, e.g., warmed to high-temperature coal, it is reduced according to the following formula:

$$
\mathrm{CO}_{2}+\mathrm{C} \rightarrow 2 \mathrm{CO}+41.2 \mathrm{kcal}
$$

The percentage of reduced dioxide depends on the surface temperature of the carbon. At $1000{ }^{\circ} \mathrm{C}$, almost all carbon dioxide is reduced to carbon monoxide. The phenomenon interferes with the objective control of fire development based on the analysis of the composition of air taken from the area where the probability of a fire is high. In practice, however, this phenomenon has not yet been significantly observed. 


\section{Results and Discussion}

The presented method made it possible to limit the endogenous fire hazard. Several measurements of the concentration of the gases that are the by-products of the process prove that their intensity in the goafs dropped and they ultimately show that the method is effective. Lower values were mainly caused by the injection of carbon dioxide together with the ash and water mixture to the goafs.

The works related to feeding the carbon dioxide together with the ash and water mixture describe that sealing the goafs can be an effective method for minimizing and combating the fire hazard. Research on fire prevention was carried out with the main aim to inertise the goaf. In total, 296,500 kg of carbon dioxide and 19,420 tonnes of the ash-water mixture were fed to the goafs during the entire operation as part of the research on combating the fire hazard. The chemical parameters of the air from goafs were measured in order to check the effectiveness of the injected ash and water mixture and carbon dioxide inertisation. The place of sampling for chromatographic analyses is indicated in Figure 3. The process of oxidation of coal and its spontaneous heating leading to spontaneous combustion is accompanied by several chemical reactions that cause the formation of gaseous products of this process-so-called fire gases. These include carbon monoxide, hydrogen, and hydrocarbons. Only the analysis of time trends in the change of all these gases allows for a realistic analysis of the processes involved in coal spontaneous combustion or its lack.

Figures 7-13 show the results obtained from the formation of carbon monoxide and unsaturated hydrocarbons of $\mathrm{C}_{2} \mathrm{C}_{4}$ group during the tests.

The results show that the concentrations of dangerous gases in the goaf air were reduced on the subsequent days of administration of the ash and water mixture. This means that there was a reduction in the carbon oxidation reaction, which ultimately leads to its spontaneous combustion. At the same time, it confirms the effectiveness of the measures taken and the application of the method developed.

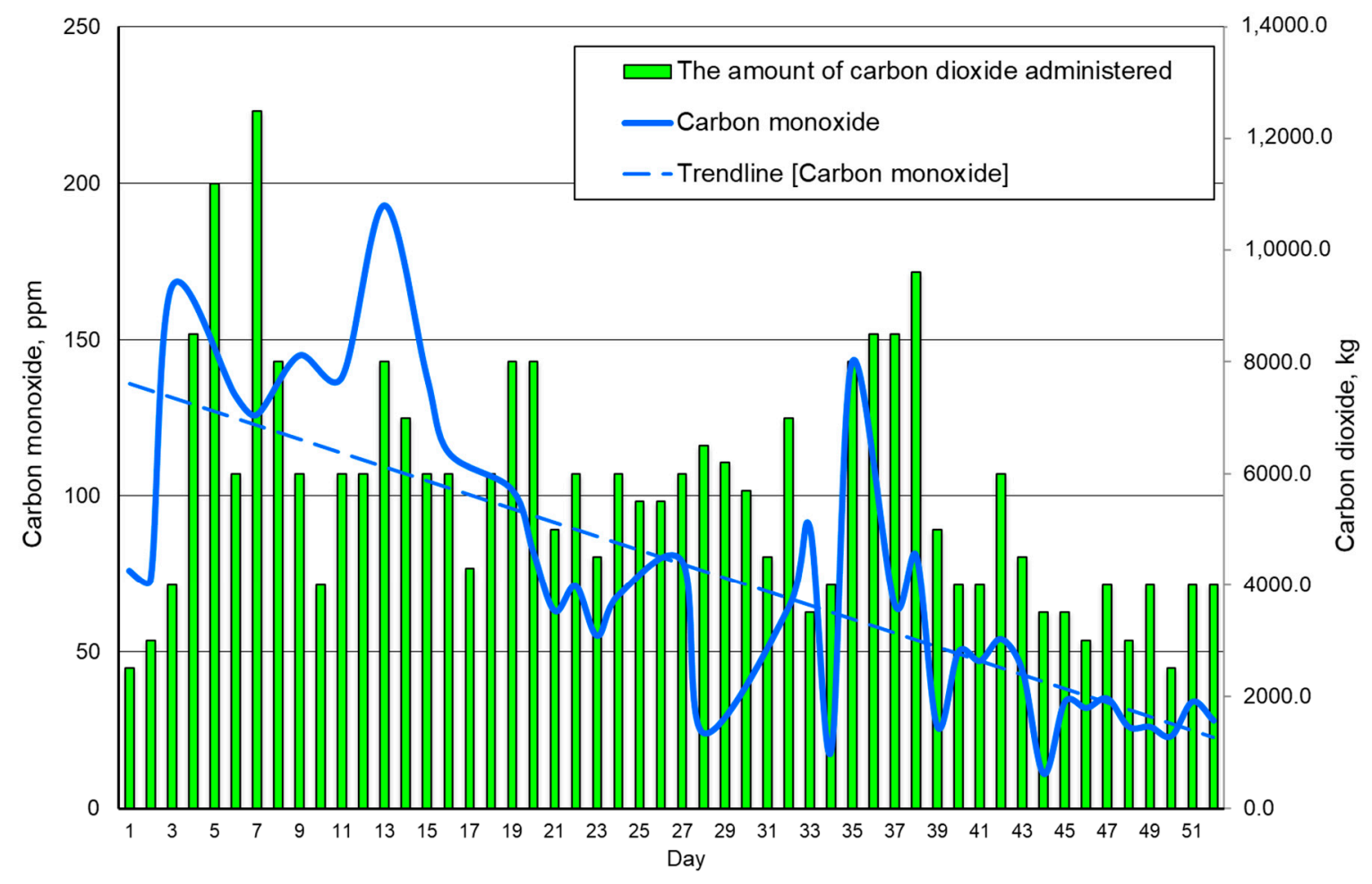

Figure 7. The value of carbon monoxide concentration in gaseous samples taken from the goafs of the analysed longwall during carbon dioxide inertisation. 


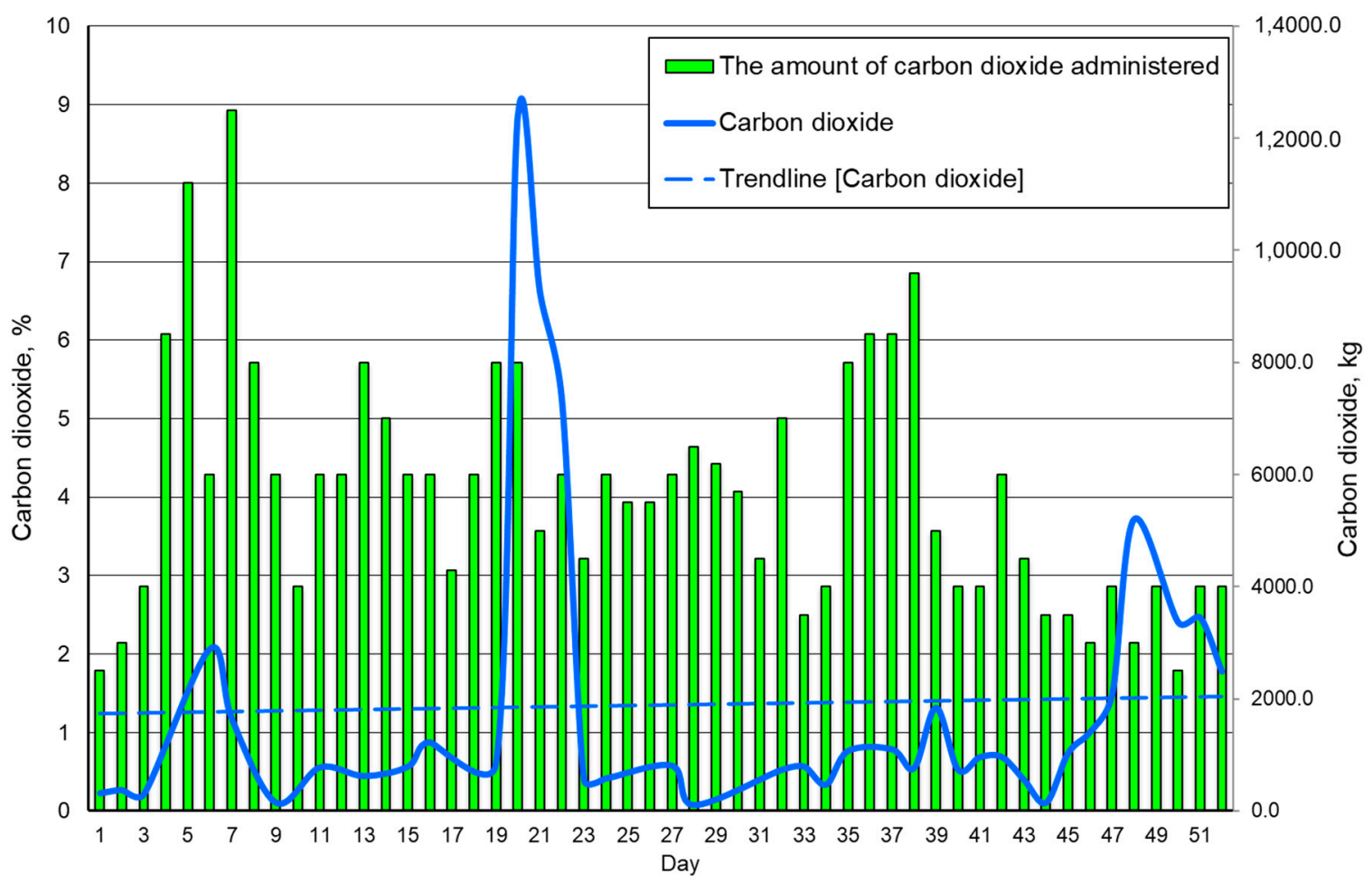

Figure 8. The value of carbon dioxide concentration in gaseous samples taken from the goafs of the analysed longwall during carbon dioxide inertisation.

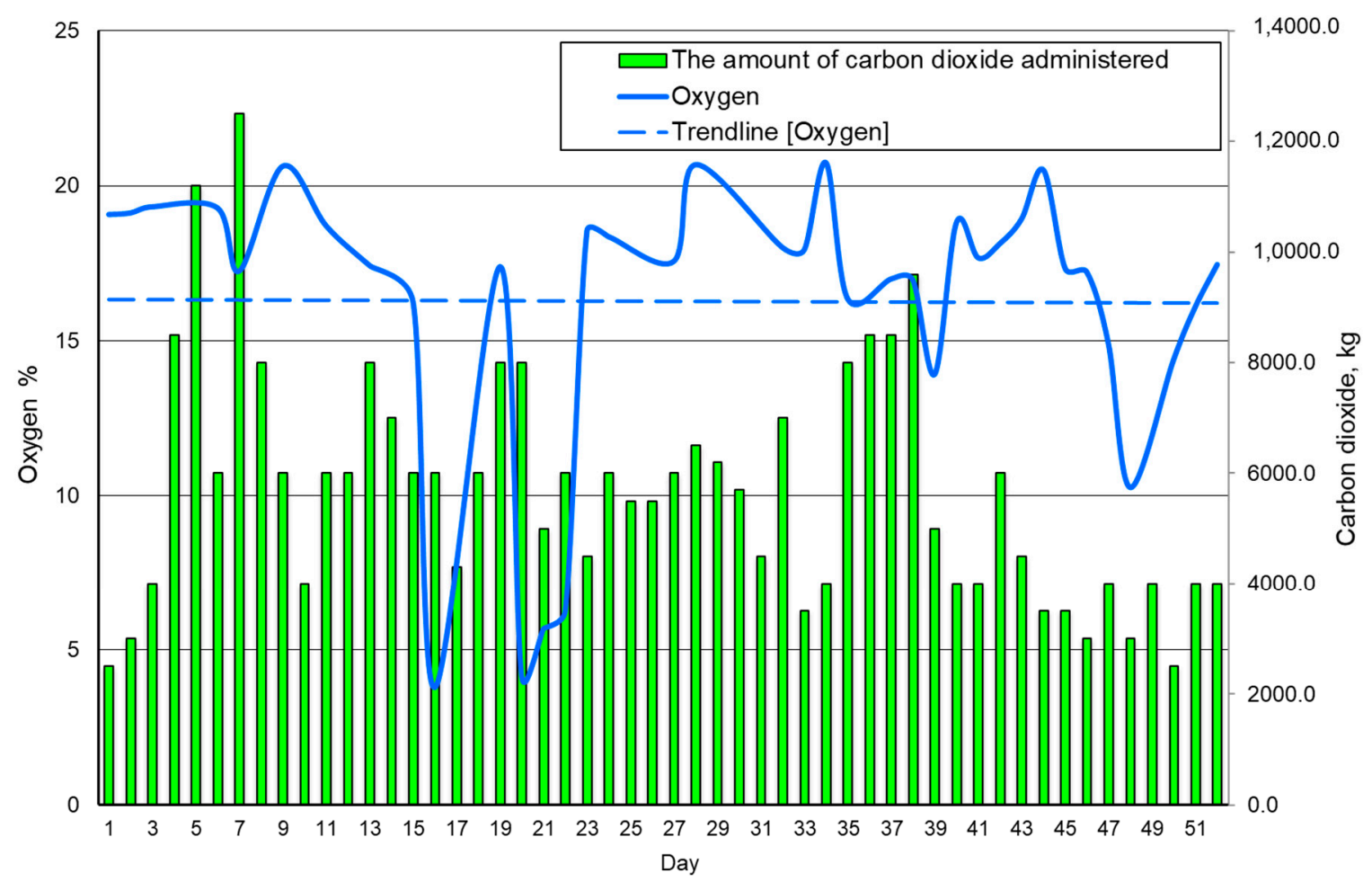

Figure 9. The value of oxygen concentration in gaseous samples taken from the goafs of the analysed longwall during carbon dioxide inertisation. 


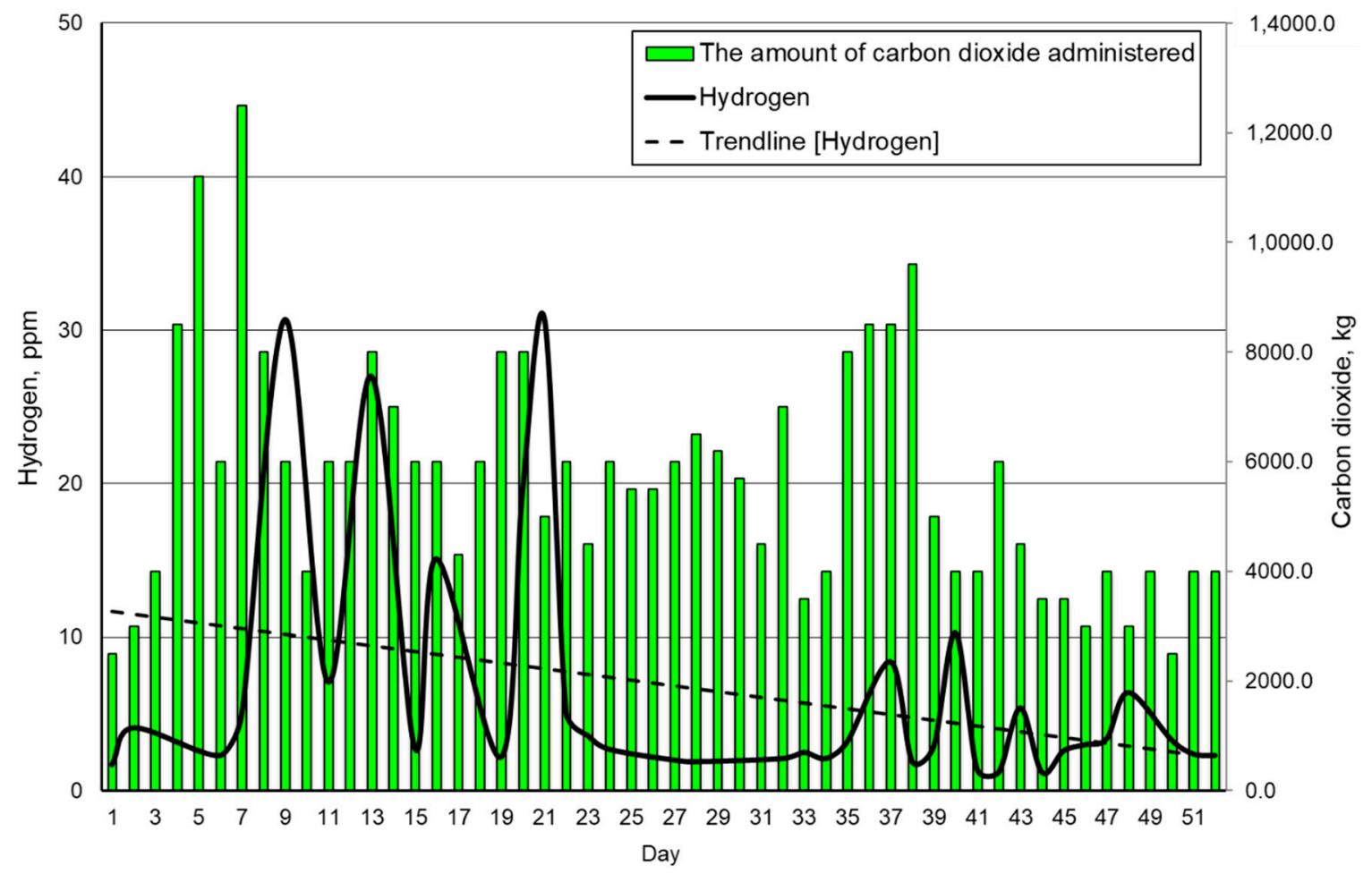

Figure 10. The value of hydrogen concentration in gaseous samples taken from the goafs of the analysed longwall during carbon dioxide inertisation.

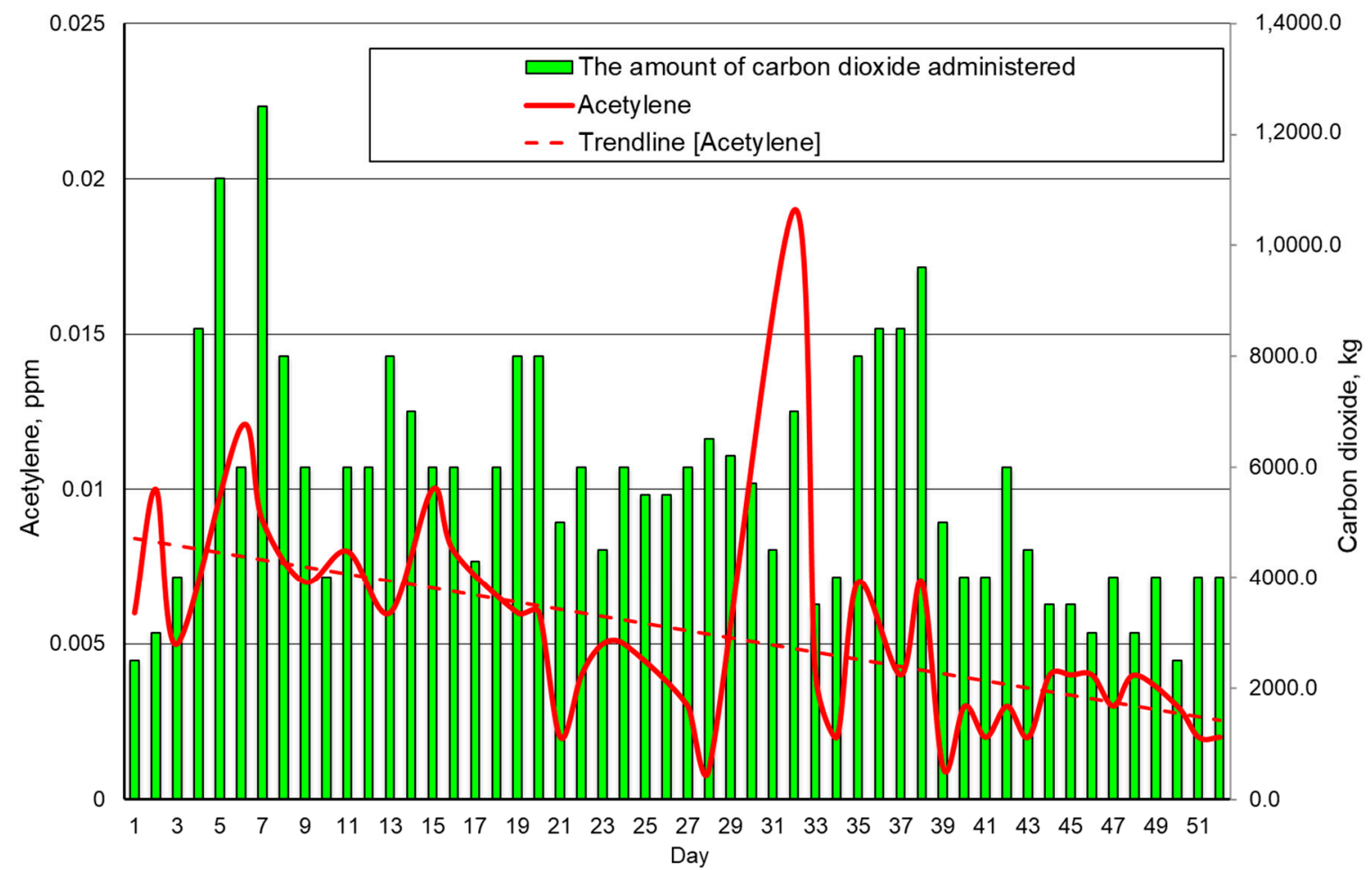

Figure 11. The value of acetylene concentration in the gas samples taken from the goafs of the analysed longwall during carbon dioxide inertisation. 


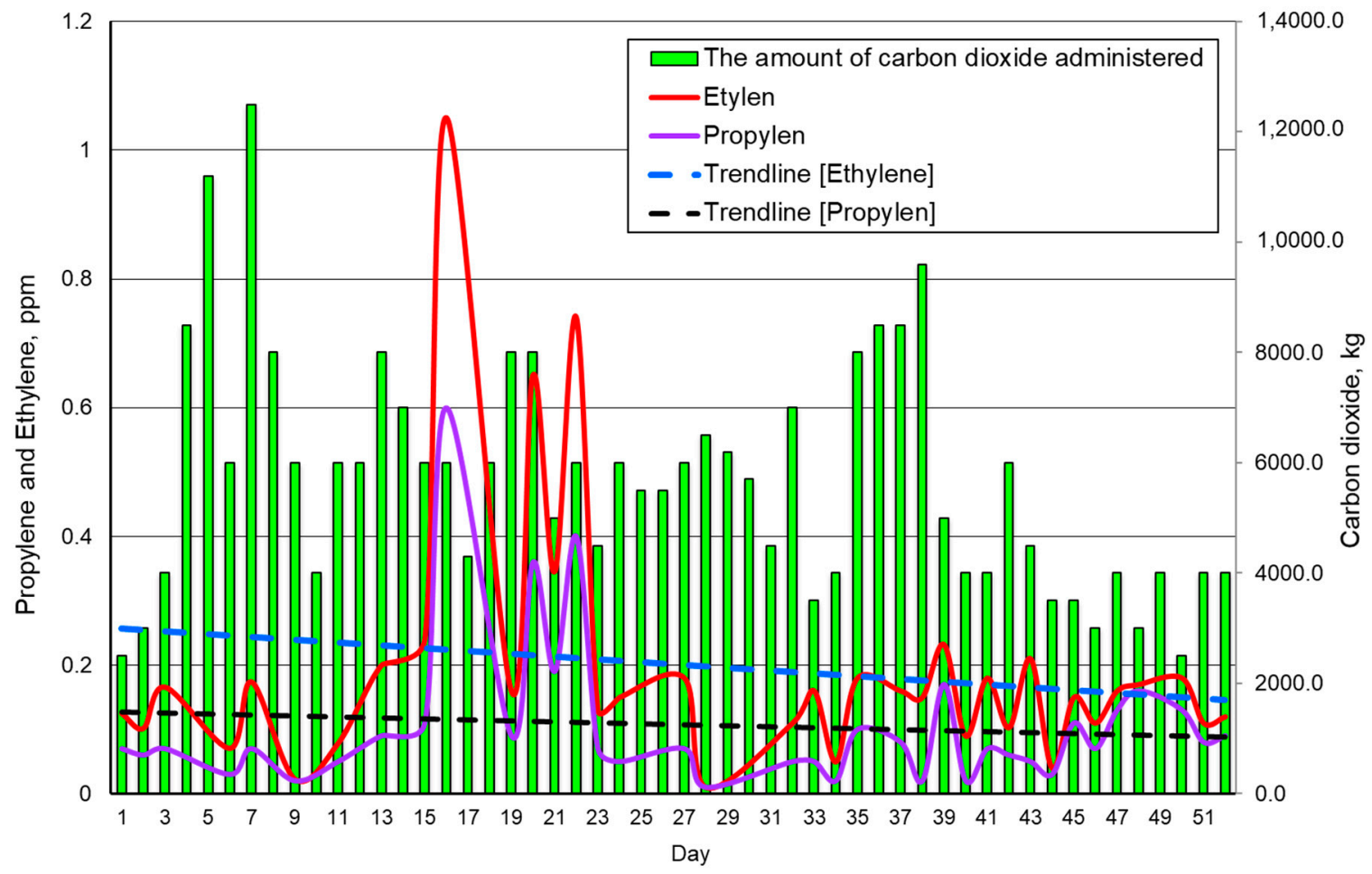

Figure 12. The value of ethylene and propylene concentration in the gas samples taken from the goafs of the analysed longwall during carbon dioxide inertisation.

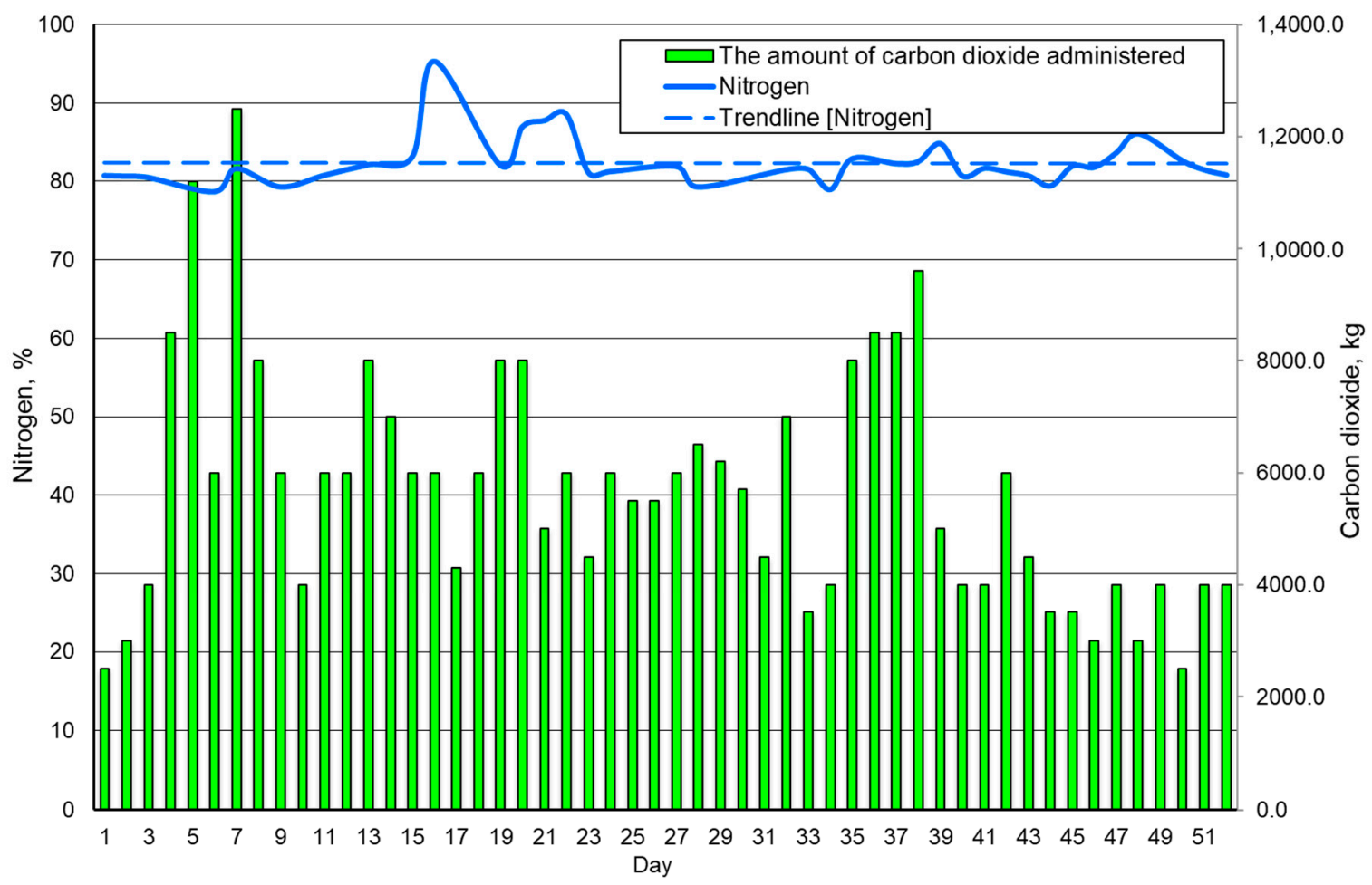

Figure 13. The value of nitrogen concentration in the gas samples taken from the goafs of the analysed longwall during carbon dioxide inertisation.

In the Polish hard coal mining industry, carbon monoxide (a toxic gas) is the most important indicator gas which shows the reactions related to the oxidation and spontaneous heating of coal leading to its spontaneous combustion. Results of carbon monoxide concentration measurements 
(Figure 7) indicate that its share in the air decreases significantly with subsequent days when the ash and water mixture and carbon dioxide were fed to the goaf. In the case of the study on the concentration of carbon dioxide (Figure 8), however, a slight upward trend was observed, which should be combined with the administration of this gas to the goafs, and not with the chemical reactions related to carbon oxidation. Since the presence of carbon dioxide in the mine atmosphere is also inseparably connected with its release from the rock mass, it is reasonable to analyse it together with the oxygen concentration (Figure 9). The analysis of changes in oxygen concentration shows that there is no decrease in the goaf air, which indicates that chemical reactions are taking place. On the 15th and 20th day of the measurement, single dynamic drops to about $4 \%$ were recorded, but this is not a concern in this case. This may be due to several factors such as a change in barometric pressure or changes in the distribution of the aerodynamic potential or the dynamic changes occurring in the rock mass during air sampling. This can also be caused by an incorrect measurement.

Hydrogen (Figure 10), acetylene (Figure 11), propylene, and ethylene (Figure 12) belong to those gases which are released into the atmosphere of the mine as the temperature of coal increases. An increase in the concentration of these gases means an increasing process of coal spontaneous heating. In the presented case, however, such a phenomenon did not occur and the concentrations of these gases showed a decreasing trend.

Moreover, analysis of nitrogen concentrations (Figure 13), in air samples taken from goafs, indicates that there are no signs of a developing endogenous fire, as its concentration does not show an upward trend. In order to correctly assess the effect of nitrogen on the risk of endogenous fires, it is necessary to compare the total oxygen (Figure 9) and nitrogen (Figure 13) concentration. If there is no carbon oxidation, the concentrations of these gases do not show a downward trend for oxygen and an upward trend for nitrogen.

Therefore, it can be concluded that the results obtained from the measurements of the concentrations of fire gases in the air samples taken from the goafs to which the ash and water mixture together with carbon dioxide was supplied, do not indicate that there is a risk of endogenous fires. These results, therefore, demonstrate the effectiveness of the method used to prevent and reduce the risk of fire in the longwalls. Intensive fire prevention with the use of ash-water mixtures fed with carbon dioxide allowed for safe operation of the analysed longwall. Early detection of fires is an extremely important factor in preventive actions with chromatographic testing and analysis playing a key role. Elevated values of carbon monoxide, as well as increased values of hydrocarbons such as ethylene, propylene, acetylene, or hydrogen at the initial stage of the spontaneous heating process of coal, allow for precise estimation of the fire hazards and rapid response. The tests carried out for the ash-water mixture together with carbon dioxide have shown:

1. Increase in the effectiveness of fire prevention measures using ash and water mixtures;

2. By combining an ash-water mixture with carbon dioxide, the risk of endogenous fires is reduced by isolating the goaf.

\section{Conclusions}

The article presents a method developed to reduce and prevent the endogenous fire hazard in goafs. This method is based on the identification of a specific fire hazard zone and then supplying it with a mixture of ash and water with an inert gas, which in this case is carbon dioxide. This method is designed and implemented to reduce the possibility of endogenous fire in goafs. The model test zone used to identify the area with unfavourable conditions allowed focusing on operational activities only on the specific area. The installation built and used for this purpose proved to be successful in delivering the right amount of water and ash mixture and carbon dioxide to this area.

The key advantage of this method is that it prevented the occurrence of endogenous fire in the tested area. This allowed for efficient and safe operation without disrupting the mining process.

Monitoring the composition of the air in the exhaust stream was vital for the assessment of the efficiency and efficacy of the developed method. This made it possible to control the concentrations of 
gases which are the products of the process of coal spontaneous heating and combustion. The time courses of these concentrations obtained and presented in the paper confirm the reliability of the solution.

The results show that the ash and water mixture together with carbon dioxide is most effective when fed as early as at the initial stage of the process of spontaneous heating of coal. The composition of the atmosphere in the goafs is a significant element of the research. Early and precise identification of the fire hazard allows for rapid and intensive preventive actions enabling a safe mining operation and later their decommissioning.

Therefore, it can be concluded that the problem of coal spontaneous combustion in the process of underground mining is common. This is particularly applied to mining in an already damaged rock mass (previous operation). This hazard, despite its slow development, is very dangerous for the continuity and efficiency of mining operation. Therefore, it is justified to develop new methods aimed at reducing it.

The key advantage of the method is that its steps are directed at only one specific area with a high probability of a dangerous event. Moreover, the simultaneous use of an ash and water mixture with carbon dioxide as an inert gas is an original approach. The application of a system for monitoring the parameters of the mixture and gas, as well as the composition of the mine atmosphere, makes it possible to monitor the effectiveness of the applied measures. The presented example, together with the results obtained, extends the knowledge on the possibilities of reducing the endogenous fire hazard. The obtained results prove that the method is effective, and it has the potential to fight unfavourable conditions in other longwalls and other conditions.

Moreover, in order to assess the state of endogenous fire hazard in goafs, it is necessary to make a full analysis of changes in the concentration of fire gases as a function of time treated as fire indicators. These gases include oxygen, nitrogen, carbon monoxide, and carbon dioxide, hydrogen, and unsaturated hydrocarbons. Analysing the concentrations of individual gases does not give a complete picture of the endogenous fire risk and can lead to invalid conclusions. This case study shows that only a full analysis of fire gases as a function of time allows assessing the effectiveness of preventive measures. External factors such as changes in the barometric pressure and the condition of the rock mass surrounding a given longwall excavation (the issue of previous exploitation and cracks in the rock mass caused by it) should also be included in the analysis.

Author Contributions: Conceptualization, M.T., J.B., D.S. and L.S.; methodology, D.S. and L.S.; software, D.S.; L.S., M.T. and J.B.; formal analysis, J.B. and M.T.; investigation, J.B. and M.T.; resources, M.T., J.B. and O.Z.; data curation, D.S., L.S., J.B. and M.T.; writing-original draft preparation, M.T.; writing-review and editing, J.B. and M.T.; visualization, D.S., M.T. and J.B.; supervision, D.S. and J.B.; project administration, M.T. and J.B.; funding acquisition, J.B. and M.T. All authors have read and agreed to the published version of the manuscript.

Funding: This publication was funded by the statutory research performed at Silesian University of Technology, Department of Safety Engineering, Faculty of Mining, Safety Engineering and Industrial Automation (06/030/BKM-20/0053).

Acknowledgments: This article is the result of statutory research performed at Silesian University of Technology, Department of Production Engineering, Faculty of Organization and Management (13/030/BK-20/0059) and the statutory research performed at Silesian University of Technology, Department of Safety Engineering, Faculty of Mining, Safety Engineering and Industrial Automation (06/030/BKM-20/0053).

Conflicts of Interest: The authors declare no conflict of interest.

\section{References}

1. BP Statistical Review of Word Energy 2019/68th Edition. Available online: https://www.bp.com (accessed on 10 May 2020).

2. International Energy Agency (IEA). World Energy Balance 2019; IEA Publications: Paris, France, 2019.

3. Restrepo, Á.; Bazzo, E.; Miyake, R. A life cycle assessment of the Brazilian coal used for electric power generation. J. Clean. Prod. 2015, 92, 179-186. [CrossRef]

4. Lin, J.; Fridley, D.; Lu, H.Y.; Price, L.; Zhou, N. Has coal use peaked in China: Near-term trends in China's coal consumption. Energy Policy 2018, 123, 208-214. [CrossRef] 
5. The Reports on the State of Hard Coal, Copper and Silver, Zinc and Lead Mining in Poland. Available online: https://min-pan.krakow.pl/projekty/2018/07/31/raport-gornictwo-wegla-kamiennego-wpolsce-2017/ (accessed on 10 May 2020).

6. Guo, W.; Guo, M.; Tan, Y.; Bai, E.; Zhao, G. Sustainable Development of Resources and the Environment: Mining-Induced Eco-Geological Environmental Damage and Mitigation Measures-A Case Study in the Henan Coal Mining Area, China. Sustainability 2019, 11, 4366. [CrossRef]

7. Cao, X.Q.; Ma, Y.; Zhao, H.Y. Eco-environmental geological problems in coal mine areas of Henan Province and its control measures. Min. Saf. Environ. Prot. 2006, 33, 130-132.

8. Xie, S.L.; Liang, D.; Yang, Q.C. Research on the Distributing Characteristics and Genesis Mechanism of Ground Fissures in Henan Province; Announcement of Geological Survey and Research of Henan Province: Zhengzhou, China, 2007.

9. Yang, Z.; Li, W.P.; Pei, Y.B.; Qiao, W.; Wu, Y.L. Classification of the type of eco-geological environment of a coal mine district: A case study of an ecologically fragile region in Western China. J. Clean Prod. 2018, 174, 1513-1526. [CrossRef]

10. Liang, Y.; Zhang, J.; Wang, L.; Luo, H.; Ren, T. Forecasting spontaneous combustion of coal in underground coal mines by index gases: A review. J. Loss Prev. Process. Ind. 2019, 57, 208-222. [CrossRef]

11. Kasap, Y. The effect of work accidents on the efficiency of production in the coal sector. S. Afr. J. Sci. 2011, 107, 5-6. [CrossRef]

12. Li, Y.; Chiu, Y.; Lin, T. Coal production efficiency and land destruction in China's coal mining industry. Resour. Policy 2019, 63, 101449. [CrossRef]

13. Xie, Z.; Cai, J.; Zhang, Y. Division of Spontaneous Combustion "Three-zone" in Goaf of Fully Mechanized Coal Face with Big Dip and Hard Roof. Procedia Eng. 2012, 43, 82-87. [CrossRef]

14. Song, S.; Wang, S.; Jiang, S.; Liang, Y.; Hu, P. Multifield Coupled Dynamic Simulation of Coal Oxidation and Self-Heating in Longwall Coal Mine Gob. Math. Probl. Eng. 2020, 2020, 1-16. [CrossRef]

15. Li, L.; Qin, B.; Ma, D.; Zhuo, H.; Liang, H.; Gao, A. Unique spatial methane distribution caused by spontaneous coal combustion in coal mine goafs: An experimental study. Process Saf. Environ. Prot. 2018, 116, 199-207. [CrossRef]

16. Palchik, V. Formation of fractured zones in overburden due to longwall mining. J. Environ. Geol. 2003, 44, 28. [CrossRef]

17. Chen, P.; Zhang, L.; Zou, D. Study of three-dimensional distribution of permeability in gob based on o-shape circle theory. Min. Saf. Environ. Prot. 2015, 42, 38-41.

18. Tutak, M.; Brodny, J. Analysis of influence of goaf sealing from tailgate on the methane concentration at the outlet from the longwall. IOP Conf. Ser. 2017, 95, 042025. [CrossRef]

19. Majdi, A.; Hassani, F.P.; Yousef Nasiri, M. Prediction of the height of destressed zone above the mined panel roof in longwall coal mining. J. Min. Environ. 2012, 9, 62-72. [CrossRef]

20. Palchik, V. Height of caved zone in weathered rock mass overlyingthe subsurface coal mines. Geophys. Res. Abstr. 2006, 8, 00851.

21. Momdal, D.; Soy, P.N.S.; Kumar, M. Monitoring the strata behavior in the Destressed Zone of a shallow Indian longwall panel with hard sandstone cover using Mine-Microseismicity and Borehole Televiewer data. Eng. Geol. 2002, 271, 105593. [CrossRef]

22. Tu, S.H.; Zhang, C.; Yang, G.Y.; Bai, Q.S.; Yan, R.L. Research on permeability evolution law of goaf and pressure-relief effect. J. Min. Saf. 2016, 33, 571-577.

23. Meng, Z.P.; Shi, X.C.; Li, G.Q. Deformation failure and permeability of coal-bearing strata during longwall mining. Eng. Geol. 2016, 208, 69-80. [CrossRef]

24. Lu, Y.; Qin, B. Identification and control of spontaneous combustion of coal pillars: A case study in the Qianyingzi mine, China. Nat. Hazards 2015, 75, 2683-2697. [CrossRef]

25. Zheng, Y.; Li, Q.; Zhang, G.; Zhao, Y.; Zhu, P.; Ma, X.; Liu, X. Effect of multi-component gases competitive adsorption on coal spontaneous combustion characteristics under goaf conditions. Fuel Process. Technol. 2020, 208, 106510. [CrossRef]

26. Li, J.; Li, Z.; Yang, Y.; Kong, B.; Wang, C. Laboratory study on the inhibitory effect of free radical scavenger on coal spontaneous combustion. Fuel Process. Technol. 2018, 171, 350-360. [CrossRef]

27. Prometegas. Available online: https://pmgpl.com.pl/cms/index.php?option=com_content\&task=view\&id= 74 (accessed on 10 May 2020). 
28. Tutak, M.; Brodny, J. Impact of type of the roof rocks on location and range of endogenous fires particular hazard zone by in goaf with caving. EPJ Web Conf. 2018, 29, 00005. [CrossRef]

29. Tutak, M.; Brodny, J. The Impact of the Strength of Roof Rocks on the Extent of the Zone with a High Risk of Spontaneous Coal Combustion for Fully Powered Longwalls Ventilated with the Y-Type System-A Case Study. Appl. Sci. 2019, 9, 5315. [CrossRef]

30. Itay, M.; Hill, C.R.; Glasser, D.A. Study of the low temperature oxidation of coal. Fuel Process. Technol. 1989, 21, 81-97. [CrossRef]

31. Deng, J.; Xiao, Y.; Li, Q.; Lu, J.; Wen, H. Experimental studies of spontaneous combustion and anaerobiccooling of coal. Fuel 2015, 157, 261-269. [CrossRef]

32. Wei, D.; Du, C.; Lei, B.; Lin, Y. Prediction and prevention of spontaneous combustion of coal from goafs in workface: A case study. Case Stud. Therm. Eng. 2020, 21, 100668. [CrossRef]

33. Zhou, F.; Ren, W.X.; Wang, D.M.; Song, T.L. Application of three-phase foam to fight an extraordinarily serious coal mine fire. Int. J. Coal Geol. 2006, 67, 95-100. [CrossRef]

34. Colaizzi, G.J. Prevention, control and/or extinguishment of coal seam fires using cellular grout. Int. J. Coal Geol. 2004, 59, 75-81. [CrossRef]

35. Ge, L.; Shao, Y.; Wang, Y.; Zhang, G.; Zhang, Z.; Liu, L. Experimental research on inerting characteristics of carbon dioxide used for fire extinguishment in a large sealed space. Process Saf. Environ. Prot. 2020, 142, 174-190. [CrossRef]

36. Adamus, A. Review of nitrogen as an inert gas in underground mines. J. Mine Vent. Soc. S. Afr. 2001, 54, 60-61.

37. Zhang, J.; An, J.; Wang, Y.; Mamun, N.; Pan, R. Philosophy of longwall goaf inertisation for coal spontaneous heating control, proactive or reactive? Int. J. Heat Mass Transf. 2019, 141, 542-553. [CrossRef]

38. Zhang, J. Underground Coal Fires in China: Origin, Detection, Fire-Fighting, and Prevention; China Coal Industry Publishing House: Beijing, China, 2008.

39. Liu, W.; Weng, F. Research on N2-inhibitor-water mist fire prevention and exting uishing technology and equipment in coal mine goaf. PLoS ONE 2019, 14, e0222003.

40. Bustamante Rúa, M.O.; Bustamante Baena, P.; Daza Aragón, A.J. Optimization of techniques for the extinction and prevention of coal fires produced in final walls as a result of spontaneous combustion in the Cerrejón mine-Colombia. Environ. Sci. Pollut. Res. 2018, 25, 32515-32523. [CrossRef] [PubMed]

41. Ren, T.; Balusu, R. Proactive goaf inertisation for controlling longwall goaf heatings. Procedia Earth Planet. Sci. 2009, 1, 309-315. [CrossRef]

42. Si, J.; Cheng, G.; Zhu, J. Optimisation of multisource injection of carbon dioxide into goafs based on orthogonal test and fuzzy comprehensive theory. Heliyon 2019, 5, e01607. [CrossRef]

43. Zhang, J.; Zhang, H.; Ren, T.; Wei, J.; Liang, Y. Proactive inertisation in longwall goaf for coal spontaneous combustion control-A CFD approach. Saf. Sci. 2019, 113, 445-460. [CrossRef]

44. Cheng, G.; Liu, Y.; Si, J. Optimization of Technical Parameters of $\mathrm{CO}_{2}$ Inerting Goaf in 7271 Working Face of Yaoqiao Mine. IOP Conf. Ser. Mater. Sci. Eng. 2019, 585, 012087. [CrossRef]

45. Classen, C. Goaf Inertisation and Sealing Utilising Methane from In-Seam Gas Drainage System. In Proceedings of the 11th Underground Coal Operators' Conference, Wollongong, Australia, 10-11 February 2011; University of Wollongong: Wollongong, Australia; The Australasian Institute of Mining and Metallurgy: Carlton, VIC, Australia, 2011; pp. 369-374.

46. Morla, R.; Balusu, R.; Tanguturi, K.; Ting, R. Inertisation options for BG method and optimisation using CFD modelling. Int. J. Min. Sci. Technol. 2015, 25, 401-405. [CrossRef]

47. Brodny, J.; Tutak, M. The impact of the flow volume flow ventilation to the location of the special hazard spontaneous fire zone in goaf with caving of operating longwalls. In Proceedings of the 16th International Multidisciplinary Scientific GeoConference (SGEM 2016), Albena, Bulgaria, 30 June-6 July 2016; Curran Associates, Inc.: Red Hook, NY, USA, 2016; Volume 2, pp. 657-664.

48. Cheng, J.; Li, S.; Zhang, F.; Zhao, C.; Yang, S.; Ghosh, A. CFD modelling of ventilation optimization for improving mine safety in longwall working faces. J. Loss Prev. Process. Ind. 2016, 40, 285-297. [CrossRef]

49. Chumak, A.S.; Pashkovsky, P.S.; Yaremchuk, M.A. Prevention of spontaneous fires by directed nitrogen supply. In Proceedings of the 7th International Mine Ventilation Congress, Crakow, Poland, 17-22 June 2001.

50. Szlązak, J.; Szlązak, N. Filtracja Powietrza Przez Zroby ścian Zawałowych w Kopalniach węgla Kamiennego; AGH Uczelniane Wydawnictwa Naukowo-Dydaktyczne: Kraków, Poland, 2005. 
51. Wang, Y.; Zhang, X.; Sugai, Y.; Sasaki, K. A Study on Preventing Spontaneous Combustion of Residual Coal in a Coal Mine Goaf. J. Geol. Res. 2015, 2015, 712349. [CrossRef]

52. Buchwald, P.; Jaskólski, Z.; Kajdasz, Z. Determining the Impact of Model Gas Mixtures on the Directions of Fire and Methane Prevention. In Materials of the Mining Aerology School; Polish Academy of Sciences Kraków: Zakopane, Poland, 2002; p. 399. Available online: http://old.e-teberia.pl/bibliografia.php?a=showarticle\& ArticleID $=6006$ (accessed on 15 August 2020).

53. Fritzsche, C.H. Lehrbuch der Bergbaukunde mit Besonderer Berücksichtigung des Steinkohlenbergbaus Erster Band; Springer: Berlin/Heidelberg, Germany, 1961.

54. Fernánez-Alaiz, F.; Castañón, A.M.; Gómez-Fernández, F.; Bernardo-Sánchez, A.; Bascompta, M. Analysis of the Fire Propagation in a Sublevel Coal Mine. Energies 2020, 13, 3754. [CrossRef]

55. Fernández-Alaiz, F.; Castañón, A.M.; Gómez-Fernández, F.; Bascompta, M. Mine Fire Behavior under Different Ventilation Conditions: Real-Scale Tests and CFD Modeling. Appl. Sci. 2020, 10, 3380. [CrossRef]

56. Bystron, H. Manometric and barometric methods of ventilation air static pressure measurement in mining workings. Przeglad Górniczy 2000, 56, 1-16.

57. Yuan, L.; Smith, A. Modeling the Effect of Barometric Pressure Changes on Spontaneous Heating in Bleederless Longwall Panels. Available online: https://www.cdc.gov/Niosh/mining/UserFiles/works/pdfs/mteob.pdf (accessed on 15 August 2020).

58. Francart, W.J.; Beiter, D.A. Barometric pressure influence in mine fire sealing. In Proceedings of the 6th International Mine Ventilation Congress, Pittsburgh, PA, USA, 17-22 May 1997; pp. 341-342.

59. Hemp, R. The effect of changes in barometric pressure on mines in the Highveld of South Africa. J. S. Afr. Inst. Min. Metall. 1994, 94, 133-146.

60. Markefka, P.; Przystolik, A.; Stefanowicz, T. Concept of aerodynamic potential's distribution structuring in underground hard coal mines to counteract the fire and gas threats associated with changes of atmospheric pressure. Przeglad Górniczy 2014, 70, 112-124.

61. Polska Grupa Górnicza, S.A. Available online: https://www.pgg.pl/o-firmie/oddzialy/1cw (accessed on 15 August 2020).

62. Deng, C.; Wang, J.; Wang, X.; Deng, H. Spontaneous coal combustion producing carbon dioxide and water. Min. Sci. Technol. (China) 2010, 20, 82-87. [CrossRef]

(C) 2020 by the authors. Licensee MDPI, Basel, Switzerland. This article is an open access article distributed under the terms and conditions of the Creative Commons Attribution (CC BY) license (http://creativecommons.org/licenses/by/4.0/). 